\title{
Effect of cassava variety, fertiliser type and dosage on the physicochemical, functional and pasting properties of high-quality cassava flour (HQCF)
}

\author{
S.A. Rasaq ${ }^{1}$, T.A. Shittu ${ }^{1}$, G.J. Fadimu ${ }^{2}$, A.B. Abass ${ }^{3,4,}$ and O. Omoniyi ${ }^{3}$ \\ ${ }^{1}$ Department of Food Science and Technology College of Food Science and Human Ecology, Federal University of Agricul- \\ ture, P.M.B. 2240, Abeokuta, Ogun State, Nigeria; ${ }^{2}$ Department of Food Science E Nutrition, College of Food and Agricul- \\ tural Sciences, King Saud University, P.O. Box 2460, Riyadh, Saudi Arabia; ${ }^{3}$ International Institute of Tropical Agriculture \\ (IITA), P.M.B. 5320, Oyo Road, Ibadan, Nigeria; ${ }^{4}$ International Institute of Tropical Agriculture (IITA), Plot 25, Light \\ Industrial Area, Coca cola Road, Dar es Salaam, Tanzania
}

Corresponding Author: G.J. Fadimu, fadimugbemisola@gmail.com

Received: 25 March 2019 / Accepted: 24 November 2019 / Published: 31 December 2019

(c) 2020 Codon Publications

OPEN ACCESS CC) (i) () RESEARCH ARTICLE

\begin{abstract}
The increase in the dry matter content of cassava due to fertiliser application has been widely reported. However, information on the effect of cassava variety, fertiliser compounding ratio and dosages on physicochemical, functional and pasting properties of high-quality cassava flour (HQCF) is scarce in the literature. This study was conducted to investigate the effect of cassava variety (TME 419 and TME 30572), fertiliser compounding ratios (NPK ratio $15-15-15,20-10-10$ and 12-12-17) and dosage (150 and $300 \mathrm{~kg} / \mathrm{ha}$ ) on some quality parameters of HQCF, and the influence of independent factors on HQCF was determined using general linear model (GLM) analysis. The result revealed that all the independent variables had significant $(p<0.05)$ effect on the physicochemical, functional and pasting properties of HQCF. The proximate composition of the flour was mostly affected by variety and fertiliser type, while the interactive effect of fertiliser type and dosage as well as the fertiliser type and variety was significant $(p<0.05)$ on the total starch content. Varietal influence was the main factor that significantly affected the amylose content of the flour samples and swelling power as well as least gelation concentration was significantly affected by fertiliser compounding ratio. In addition, interaction of fertiliser type and dosage had significant effect on swelling power. Pasting properties of the flour samples were mostly influenced by fertiliser type and cassava varieties, while dosage did not show significant influence on the flour properties. Peak viscosity value, which varied from 462.58 to 534.67 RVU, is the pasting property that was mostly affected by the independent factors. This study clearly indicates that cassava varieties and fertiliser treatment could influence the functionality of HQCF in food systems.
\end{abstract}

Keywords: cassava varieties; fertiliser compounding ratio; fertiliser dosage; HQCF; quality attributes

\section{Introduction}

Cassava (Manihot esculenta Crantz) is an important tropical root crop. Its starchy roots are an important source of calories in the tropics, providing energy nourishment for more than 500 million to 1 billion people worldwide (Sornyotha et al., 2010). Nigeria is the leading producer of cassava roots in the world. In the year 2017, Nigeria produced 59 million metric tons of cassava roots, which was about $18 \%$ of the total world production (FAOSTAT, 2019). With rising wheat prices on the global market, there is an interest to promote the utilisation of local sources of flour for the partial substitution of wheat flour in food products in order to reduce the dependency on wheat imports and also to increase the livelihoods of local farmers. Current status of research in West Africa and in Nigeria has focused on the production of high-quality cassava flour (HQCF) for use in the food industry. HQCF provides the best alternative to flour production for baked products. Several food products prepared from wheat, rice and corn starches can be made using cheap and 
readily available stable product such as HQCF as a partial or total substitute. Cakes, cookies, bread and other confectioneries have been successfully made from HQCF.

HQCF is one of the numerous products that are obtained from cassava roots. HQCF is unfermented, white, smooth and odourless cassava flour with no gluten and has been used as a local inclusion into wheat flour for use in the baking industry (Oti et al., 2010). It is produced from freshly harvested sweet cassava variety and rapidly processed cassava roots. Optimum utilisation of cassava flour in composite bread production could be a catalyst for rural industrial development by raising the income levels of farmers, processors and traders as well as ensuring the nutrition and food security status of Nigerians (Balagopalan, 2002; Plucknett et al., 1998). Cassava flour has been reported to contain $0.2 \%$ fat, $0.5 \%$ fibre, $1.7 \%$ ash, $85 \%$ starch and $0.7 \%$ protein (Darkwa and Jetuah, 2003). In addition to its high-energy content, it is also a rich source of minerals and vitamins. However, these nutrients usually exist in lower concentrations in cassava flour when compared with flour from cereals such as wheat and corn. Generally, cassava flour is processed from the sweet variety of cassava, a variety known to contain very low level of cyanogenic glucoside, and elimination of cyanogenic glucoside is achieved during peeling, grating and dewatering operations. The starch of cassava is capable of forming a strong gel and could be used as a composite flour of good binding property (Oparah et al., 2013).

A study by Nweke (1996) reported that cassava root has the potential to bridge the food security gap in Africa. However, cassava yield is generally low due to poor soil fertility (Nweke, 1996). The poor soil fertility is also accelerated by failure of farmers to apply fertilisers. To increase the yield potential of cassava, the crop had been reported to respond to good soil fertility and adequate fertiliser. Fertiliser application supplies the major soil nutrients such as nitrogen, phosphorus and potassium needed for plant growth. NPK fertiliser, which contains the three macro-nutrients, nitrogen, phosphorus and potassium, needed by plants, is the most commonly used fertiliser in cassava cultivation. Addition of these soil nutrients will translate to starch synthesis and expressed in variation of starch and flour quality (Gomez et al., 1980). Many previous works were devoted to determining the effect of cassava genotype and the level of wheat flour substitution with cassava flour on their bread-making quality (Adeyemi and Idowu, 1990; Defloor et al., 1993). However, fewer studies considered the effect of nitrogen treatment on chemical composition and the quality of food product from such roots (Mensah, 2013; Shittu et al., 2008).

Shittu et al. (2008) showed that the quality of flour from cassava varieties was affected by the application of NPK fertiliser. However, the author reported only one fertiliser type and compound dosage ratio of 15/15/15 at $150 \mathrm{~kg} / \mathrm{ha}$. Information on the effects of several fertiliser compounding ratio and dosage on physicochemical, functional and pasting properties of HQCF is scarce. This study was therefore conducted to evaluate the effects of different cassava varieties, fertilisers compounding ratio and dosage on physical, chemical and functional properties of HQCF using general linear model (GLM) analysis.

\section{Materials and methods}

\section{Materials}

Two varieties of cassava grown with three different fertiliser protocols were obtained from the research site of the International Institute of Tropical Agriculture (IITA) experimental station in Ikenne, Ogun State, Nigeria. The varieties were: TME 419 and TMS 30572. The cassava varieties were harvested at 12 months after planting. Immediately after harvest, the cassava roots were transported to the processing laboratory for processing in order to prevent fermentation. All chemicals used were of analytical grade and procured from Sigma Aldrich Co. (St Louis, MO, USA).

\section{Preparation of high-quality cassava flour}

Freshly harvested cassava roots from the two varieties and different fertiliser treatments were processed into HQCF using Adekunle et al's (2012) method within 24 h from the time of harvest to drying in order to produce good-quality flour that conforms to the set standard. The cassava tubers were peeled, thoroughly washed and grated into a mash with a grater (model SD-500, Henan, China). The mash was then dewatered by manual pressing in clean woven sacks, the lumps were pulverized and the mash was solar dried on a raised platform in a solar house (direct natural convection solar drier). The dried mash was then milled into flour using the disc attrition milling machine. The flour was sieved with a $0.25-\mathrm{mm}$ sieve to obtain very fine HQCF. The flour was packaged in a polythene bag stored at $4^{\circ} \mathrm{C}$ for analysis.

\section{Experimental design to produce HQCF}

A $2 \times 3 \times 2$ factorial design involving two cassava varieties (TMS 30572 and TMS 419) and three compounding fertiliser ratios (NPK 15-15-15: $\mathrm{N}=15, \mathrm{P}=15, \mathrm{~K}=15$; 20-1010: $\mathrm{N}=20, \mathrm{P}=10, \mathrm{~K}=10$; and 12-12-17: $\mathrm{N}=12, \mathrm{P}=12$, $\mathrm{K}=17$ ) at two dosage levels of fertiliser (150 and $300 \mathrm{~kg} /$ ha) was designed using general linear model (GLM) analysis. In each case, the compounding ratios 15-15-15, 2010-10 and 12-12-17 represent the percentage of nitrogen, phosphorus and potassium in the fertiliser. The 12 experimental runs and two control samples (unfertilised TMS 30572 and TMS 419) generated are presented in Table 1.

\section{Proximate composition of HQCF samples}

The proximate composition (moisture content, crude protein, crude fibre and ash) of the HQCF samples was 
Table 1. Experimental design.

\begin{tabular}{lcc} 
Cassava variety & Fertiliser type (NPK) & Fertiliser dosage $\mathbf{( k g / h a )}$ \\
\hline TMS 30572 & $15-15-15$ & 150 \\
TMS 30572 & $15-15-15$ & 300 \\
TMS 30572 & $20-10-10$ & 150 \\
TMS 30572 & $20-10-10$ & 300 \\
TMS 30572 & $12-12-17$ & 150 \\
TMS 30572 & $12-12-17$ & 300 \\
TMS 30572 & NF & - \\
TME 419 & $15-15-15$ & 150 \\
TME 419 & $15-15-15$ & 300 \\
TME 419 & $20-10-10$ & 150 \\
TME 419 & $20-10-10$ & 300 \\
TME 419 & $12-12-17$ & 150 \\
TME 419 & $12-12-17$ & 300 \\
TME 419 & NF & - \\
\hline
\end{tabular}

NF, no fertiliser (control sample).

determined as described by AOAC (2000), while the carbohydrate content was calculated by difference method using the following formula:

$\%$ Carbohydrate $=100-($ Protein +

Moisture + Fat + Fibre + Ash)

\section{Determination of physicochemical properties of HQCF}

\section{$\mathrm{pH}$}

Five gram of flour (dry basis) was taken in a clean dried beaker and $25 \mathrm{ml}$ of distilled water was added into it and stirred to obtain a homogenous mixture. The mixture was left to settle for $10 \mathrm{~min}$. A calibrated $\mathrm{pH}$ meter (Model HI 2210, HANNA Instruments, Romania) was immersed into the water phase of the mixture and the $\mathrm{pH}$ reading was recorded (AOAC, 2000).

\section{Determination of total titratable acidity of HQCF}

Titratable acidity was determined using AOAC (2000) method, where $25 \mathrm{ml}$ of the filtrate obtained from $5 \mathrm{~g}$ of HQCF sample dissolved in $50 \mathrm{ml}$ of distilled water against $0.1 \mathrm{~N} \mathrm{NaOH}$ using phenolphthalein as indicator was titrated. An amount of $1 \mathrm{ml}$ of $0.1 \mathrm{~N} \mathrm{NaOH}$ will be taken as equivalent to $9.008 \times 10^{-3}$ g lactic acid. A flour sample of $1 \mathrm{~g}$ was added into a conical flask and $20 \mathrm{ml}$ of ethanol was added to it and mixed together; then $0.2 \mathrm{ml}$ of phenolphthalein indicator solution was added to the mixture. It was titrated while shaking with $0.1 \mathrm{~N} \mathrm{NaOH}$ until pink colour appeared and persisted for about $10 \mathrm{~s}$. A blank titration was also carried out. The percentage TTA was calculated using the following formula:

$\% T T A=\frac{(\mathrm{V}-\mathrm{B}) \times \mathrm{N} \times 100}{\mathrm{~W}}$

where:

$\mathrm{V}=$ Volume of the titrant $(\mathrm{NaOH})$ consumed for sample $\mathrm{B}=$ Volume of the titrant consumed for blank

$\mathrm{N}=$ Normality of the titrant $(\mathrm{NaOH})$

$\mathrm{W}=$ Weight of the sample

\section{Determination of amylose content of HQCF}

The formation of helical complex between amylose and iodine gives rise to the typical deep blue colour of starch dispersion stained with iodine, and this forms the basis for quantitative determination of amylose content (Williams et al., 1970); $100 \mathrm{mg}$ of the flour sample was added into a flask, and $1 \mathrm{ml}$ of distilled ethanol and $10 \mathrm{ml} 1 \mathrm{~N} / 0.1 \mathrm{~N}$ $\mathrm{NaOH}$ were added and the mixture was heated for $10 \mathrm{~min}$; $20 \mathrm{ml}$ of distilled water and three drops of phenolphthalein indicator were added to $2.5 \mathrm{ml}$ of the extract. After this, 0.1 N HCL was added drop by drop until the pink colour disappears. $1 \mathrm{M}$ iodine reagent was added and the volume was made up to $50 \mathrm{ml}$, and the colour was read at $590 \mathrm{~nm}$; 0.2 , 0.4, 0.6, 0.8 and $1 \mathrm{ml}$ of standard amylose were taken, and the colour was developed as in the case of the sample. The amount of amylose present in the sample was calculated using the following formula, and $1 \mathrm{ml}$ of iodine reagent was diluted with $50 \mathrm{ml}$ distilled water to obtain the blank:

$$
\begin{aligned}
& \text { Amylose }(\mathrm{mg} / \mathrm{kg})= \\
& \text { Conc } \times \text { Volume of sample } \times \text { Dilution factor }
\end{aligned}
$$$$
\text { Sample weight }
$$

\section{Determination of starch and sugar contents of HQCF}

The starch and total sugars content were determined using a colorimetric method described earlier (Onitilo et al., 2007). This involved weighing $0.02 \mathrm{~g}$ of the sample in a centrifuge tube with $1 \mathrm{ml}$ cold ethanol, $2 \mathrm{ml}$ distilled water and $10 \mathrm{ml}$ hot ethanol. The mixture was vortexed and centrifuged at $2000 \mathrm{rpm}$ for 10 min. The supernatant was decanted and used for the determination of the sugar content, while the sediment was hydrolysed with perchloric acid and used to estimate the starch content. Phenol-sulphuric reagent was used for colour development, and glucose standards were used for the estimation of sugar. The absorbance was read with a spectrophotometer (T60 UV Visible) at $490 \mathrm{~nm}$. 


\section{Determination of hydrogen cyanide}

Quantitative determination of hydrogen cyanide was carried out using Essers et al.'s (1993) method. An extract was made from the flour blends and extrudates using cold orthophosphoric acid. The extract was treated with an excess amount of exogenous linamarase; the $\mathrm{pH}$ was raised to convert all cyanohydrins and hydrogen cyanide to cyanide ions. Cyanide ions were quantified using a specific and stoichiometric reaction with chloramine $\mathrm{T}$, isonicotinate and dimethyl barbituric, which produces a coloured dye. The absorbance of the colour produced is proportional to the concentration of cyanide ions in the reaction mixture.

\section{Functional properties of HQCF}

\section{Determination of bulk density}

Bulk density of plantain flours was determined using Fadimu et al.'s (2018b) method; a $100 \mathrm{ml}$ measuring cylinder was filled with the sample to mark $100 \mathrm{ml}$; the cylinder was tapped 50 times and then reweighed. Bulk density was calculated as the ratio of the bulk density and the volume of the container $(\mathrm{g} / \mathrm{ml})$.

\section{Determination of water absorption capacity}

Water absorption capacity of the plantain flour was determined as described by Sathe and Salunkhe (1981). One gram of the sample was mixed with $10 \mathrm{ml}$ of distilled water. The mixture was allowed to stand at room temperature for $30 \mathrm{~min}$ and then centrifuged at $1.073 \times \mathrm{g}$ for $15 \mathrm{~min}$. The water absorption capacity was expressed as percentage increase in the weight of the sample.

\section{Determination of swelling power and solubility index}

Swelling power and solubility index were determined as described by Leach et al. (1959); 1\% flour solution was prepared and heated in a water bath (Gallenkamp Water bath Model BKS-350-030), maintained at $90^{\circ} \mathrm{C}$ for 30 min with constant stirring and cooling. The suspension was centrifuged at $3000 \mathrm{rpm}$ for $20 \mathrm{~min}$, and the supernatant was decanted into a pre-weighed can and dried at $100^{\circ} \mathrm{C}$ to constant weight. The dried can was weighed for solubility calculation, while the weight of wet sediment in the centrifuge tube was used to determine the swelling power.

\section{Determination of dispersibility}

Dispersibility of the plantain flour was determined using Kulkarni and Ingle's (1991) method. Ten grams of the flour sample was suspended in a $100 \mathrm{ml}$ measuring cylinder and distilled water was added to reach a volume of $100 \mathrm{ml}$. The mixture was stirred vigorously and allowed to settle for $3 \mathrm{~h}$. The volume of the settled particles was recorded and subtracted from 100, and the difference was reported as percentage dispersibility.

\section{Determination of least gelation concentration of HQCF}

Gelation property was determined according to Coffman and Garcia's (1977) method. Sample suspensions of $2-20 \%(\mathrm{w} / \mathrm{w})$ were prepared in distilled water, and the dispersions were transferred into a test tube. It was heated in a boiling water bath for $1 \mathrm{~h}$, followed by rapid cooling in a cold water bath. The test tubes were further cooled at $4^{\circ} \mathrm{C}$ for $2 \mathrm{~h}$. The least gelation concentration was determined as the concentration when the sample from the inverted test tube did not slip or fall.

\section{Pasting properties of HQCF}

Pasting characteristics were determined by using a Rapid Visco Analyser (RVA TECMASTER, Perten Instruments North America, Springfield, IL, USA). Parameters estimated were peak viscosity, setback viscosity, final viscosity, pasting temperature and time to reach peak viscosity. About $3.50 \mathrm{~g}$ of the sample was weighed to the nearest $0.01 \mathrm{~g}$ in the test canister and $25 \mathrm{ml}$ of distilled water was dispensed into the canister. The canister was thereafter lowered into the RVA system and the slurry was heated from 50 to $95^{\circ} \mathrm{C}$ and then cooled rapidly to $50^{\circ} \mathrm{C}$ within 12 min, rotating the can at a speed of $160 \mathrm{rpm}$ with continuous stirring of the content with a plastic paddle. Parameters estimated were peak viscosity, trough viscosity, breakdown viscosity, setback viscosity, final viscosity, pasting temperature and pasting time.

\section{Statistical analysis}

All analyses were conducted in triplicate. The results were expressed as mean \pm standard deviation. Statistical analysis was carried out using one-way analysis of variance (ANOVA) with IBM SPSS 21.0 version (Michigan State University, East Lansing, MI). Duncan's multiple range test was used for mean separation.

\section{Results and discussion}

\section{Effect of cassava varieties, fertiliser type and dosage on the chemical composition of HQCF}

Table 2 shows the effect of cassava variety, fertiliser compounding ratio and dosage on the chemical composition of HQCF. The values of moisture content, ash, crude fat, 
Table 2. Effect of variety, fertiliser type and dosage on the chemical composition of HQCF.

\begin{tabular}{|c|c|c|c|c|c|c|c|c|c|}
\hline Variety & $\begin{array}{l}\text { Fertiliser } \\
\text { type (NPK) }\end{array}$ & $\begin{array}{l}\text { Dosage } \\
\text { (kg/ha) }\end{array}$ & $\begin{array}{c}\text { Moisture } \\
(\%)\end{array}$ & $\begin{array}{l}\text { Ash } \\
(\%)\end{array}$ & $\begin{array}{l}\text { Fat } \\
(\%)\end{array}$ & $\begin{array}{c}\text { Fibre } \\
(\%)\end{array}$ & $\begin{array}{c}\text { Protein } \\
(\%)\end{array}$ & $\begin{array}{l}\mathrm{CHO} \\
(\%)\end{array}$ & $\begin{array}{c}\text { Dry matter } \\
(\%)\end{array}$ \\
\hline TMS 30572 & $15-15-15$ & 150 & $9.03 \pm 1.05^{c}$ & $0.71 \pm 0.02^{h}$ & $0.58 \pm 0.00^{\mathrm{abc}}$ & $1.19 \pm 0.01^{1 \mathrm{abcd}}$ & $2.38 \pm 0.03^{\mathrm{bc}}$ & $86.61 \pm 0.97^{b c}$ & $90.97 \pm 1.89^{d}$ \\
\hline TMS 30572 & $15-15-15$ & 300 & $10.06 \pm 0.58^{\mathrm{de}}$ & $0.73 \pm 0.01^{i}$ & $0.61 \pm 0.02^{\mathrm{abcd}}$ & $1.46 \pm 0.02^{\text {def }}$ & $2.33 \pm 0.04^{\mathrm{bc}}$ & $84.81 \pm 1.45^{\mathrm{ab}}$ & $89.94 \pm 1.58^{\text {bc }}$ \\
\hline TMS 30572 & $20-10-10$ & 150 & $9.00 \pm 0.05^{\mathrm{c}}$ & $0.460 .01^{a}$ & $0.59 \pm 0.01^{\mathrm{abc}}$ & $1.23 \pm 0.00^{\mathrm{bcd}}$ & $2.57 \pm 0.01^{\mathrm{bc}}$ & $86.15 \pm 1.08^{\mathrm{bc}}$ & $91.00 \pm 2.48^{d}$ \\
\hline TMS 30572 & $20-10-10$ & 300 & $11.39 \pm 1.05^{f}$ & $0.57 \pm 0.00^{c}$ & $0.53 \pm 0.02^{\mathrm{a}}$ & $1.52 \pm 0.00^{\mathrm{ef}}$ & $2.37 \pm 0.00^{\mathrm{bc}}$ & $83.62 \pm 0.36^{a}$ & $88.61 \pm 2.75^{a}$ \\
\hline TMS 30572 & $12-12-17$ & 150 & $10.32 \pm 0.26^{\mathrm{e}}$ & $0.67 \pm 0.00^{f}$ & $0.59 \pm 0.01^{\mathrm{abc}}$ & $1.17 \pm 0.00^{\mathrm{abcd}}$ & $2.51 \pm 0.02^{b c}$ & $84.74 \pm 1.79^{\mathrm{ab}}$ & $89.67 \pm 1.49^{b}$ \\
\hline TMS 30572 & $12-12-17$ & 300 & $7.50 \pm 0.25^{\mathrm{ab}}$ & $1.05 \pm 0.00^{\mathrm{j}}$ & $0.61 \pm 0.02^{\mathrm{abcd}}$ & $1.30 \pm 0.00^{\text {cde }}$ & $2.17 \pm 0.00^{\mathrm{bc}}$ & $87.37 \pm 3.48^{c d}$ & $92.50 \pm 2.78^{\mathrm{ef}}$ \\
\hline TMS 30572 & $\mathrm{NF}$ & - & $8.50 \pm 0.15^{\mathrm{bc}}$ & $0.61 \pm 0.00^{d}$ & $0.57 \pm 0.01^{\mathrm{abc}}$ & $1.21 \pm 0.00^{\mathrm{bcd}}$ & $1.90 \pm 0.00^{\mathrm{a}}$ & $87.21 \pm 2.47^{c d}$ & $92.00 \pm 1.68^{e}$ \\
\hline TME 419 & $15-15-15$ & 150 & $8.00 \pm 0.47^{b}$ & $0.69 \pm 0.00^{9}$ & $0.65 \pm 0.00^{\mathrm{bcd}}$ & $0.91 \pm 0.00^{\mathrm{a}}$ & $2.67 \pm 0.04^{\mathrm{bc}}$ & $87.08 \pm 0.94^{\text {cd }}$ & $92.00 \pm 2.73^{\mathrm{e}}$ \\
\hline TME 419 & $15-15-15$ & 300 & $8.00 \pm 0.67^{b}$ & $0.66 \pm 0.01^{\text {ef }}$ & $0.56 \pm 0.02^{\mathrm{ab}}$ & $1.13 \pm 0.01^{\mathrm{abc}}$ & $2.28 \pm 0.00^{\mathrm{bc}}$ & $87.37 \pm 0.71^{\mathrm{cd}}$ & $93.00 \pm 0.36^{f}$ \\
\hline TME 419 & $20-10-10$ & 150 & $7.00 \pm 0.02^{\mathrm{a}}$ & $0.62 \pm 0.00^{d}$ & $0.62 \pm 0.01^{\mathrm{abcd}}$ & $1.29 \pm 0.02^{\text {bcde }}$ & $2.44 \pm 0.01^{\mathrm{bc}}$ & $88.03 \pm 2.46^{d}$ & $90.66 \pm 0.36^{\text {cd }}$ \\
\hline TME 419 & $20-10-10$ & 300 & $9.34 \pm 0.56^{c d}$ & $0.71 \pm 0.00^{h}$ & $0.66 \pm 0.02^{c d}$ & $1.10 \pm 0.02^{\mathrm{abc}}$ & $2.74 \pm 0.02^{b c}$ & $85.45 \pm 0.46^{b}$ & $91.60 \pm 2.48^{\mathrm{de}}$ \\
\hline TME 419 & $12-12-17$ & 150 & $8.41 \pm 0.47^{\mathrm{bc}}$ & $0.65 \pm 0.00^{\mathrm{e}}$ & $0.63 \pm 0.01^{\mathrm{abcd}}$ & $1.01 \pm 0.02^{\mathrm{abc}}$ & $2.10 \pm 0.02^{\mathrm{bc}}$ & $87.20 \pm 2.89^{\text {cd }}$ & $92.50 \pm 2.37^{\mathrm{ef}}$ \\
\hline TME 419 & $12-12-17$ & 300 & $7.50 \pm 0.47^{\mathrm{ab}}$ & $0.58 \pm 0.01^{c}$ & $0.61 \pm 0.01^{\mathrm{abcd}}$ & $1.00 \pm 0.01^{\mathrm{ab}}$ & $2.76 \pm 0.02^{c}$ & $87.55 \pm 1.09^{\text {cd }}$ & $91.50 \pm 1.79^{d}$ \\
\hline TME 419 & $\mathrm{NF}$ & - & $7.50 \pm 0.42^{\mathrm{ab}}$ & $0.56 \pm 0.01^{b}$ & $0.70 \pm 0.01^{\mathrm{d}}$ & $1.61 \pm 0.02^{f}$ & $1.20 \pm 0.10^{\mathrm{a}}$ & $88.43 \pm 0.89^{d}$ & $92.50 \pm 2.70^{\text {ef }}$ \\
\hline \multicolumn{10}{|c|}{ The superscript is used to show significant differences among the samples. } \\
\hline \multicolumn{10}{|c|}{ Values are means of triplicate determination. } \\
\hline \multicolumn{10}{|c|}{ Mean values with different superscripts within the same column are significantly different $(p<0.05)$. } \\
\hline QLF, nig & & & 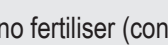 & & & & & & \\
\hline
\end{tabular}

crude fibre, protein, carbohydrate and dry matter for the flour samples varied from 7.50 to $11.39 \%, 0.46$ to $1.05 \%$, 0.53 to $0.70 \%, 0.91$ to $1.52 \%, 1.20$ to $2.76,83.62$ to 88.43 and 88.61 to $93.00 \%$, respectively, and were significantly different $(p<0.05)$ from each other. The values reported for some of these parameters are consistent with those reported in previous studies (Moorthy, 2002). The moisture content of the flour obtained in this study was lower than $10 \%$ maximum recommended for dried products, and the lower the moisture content of a stored product, the better the storage stability (Sanni et al., 2005). The level of moisture observed in this study may be attributed to varietal influence and/or fertiliser uptake. The protein content of the flours ranged from 1.20 to $2.76 \%$ with the highest value reported in TME 419 variety with 20-10-10 NPK compounding ratio at $300 \mathrm{~kg} / \mathrm{ha}$. HQCF from unfertilised TME and TMS cassava varieties had significantly lower protein content than the flour from fertilised cassava roots. This implies that fertiliser application to the cassava root could enhance the protein content of the flour from the root. Compared to flour from cereals including wheat, corn and rice, the protein content of cassava flour is generally low.

The ash content provides information about the mineral composition of a sample. The ash values obtained in this study were lower than the values reported by Shittu et al. (2008), who reported a mean ash value of $1.5 \%$ for HQCF from fertilised roots. The highest ash value was found in the HQCF sample from cassava variety TMS 30572 with NPK 12:12:17 at $300 \mathrm{~kg} / \mathrm{ha}$, suggesting an increase in the potassium content of the soil following fertiliser application. Dry matter is an essential chemical indicator of food quality in root and tuber crops (Assanvo et al., 2006), and it determines the textural quality of foods (Izutsu and Wani, 1985). The values obtained for dry matter in this study are consistent with those reported by Moorthy (2002). Differences in chemical composition of cassava flour due to varietal differences have been reported (Aryee et al., 2006), and this may influence the utilisation of the flour for food and industrial use.

\section{Effect of cassava varieties, fertiliser type and dosage on physicochemical properties of HQCF}

Effect of cassava varieties, fertiliser type and dosage on physicochemical properties of HQCF is presented in Table 3. Significant difference $(p<0.05)$ was observed in total titratable acidity (TTA), $\mathrm{pH}$, total starch, soluble sugar, amylose and hydrogen cyanide $(\mathrm{HCN})$ content of the flour samples. The TTA and pH of the flour samples ranged from 13.90 to $17.68 \%$ and 5.09 to 6.24 , respectively. Total starch, soluble sugar, amylose and HCN content of the HQCF samples ranged from 66.82 to $83.23 \%, 2.67$ to $4.42 \%, 20.29$ to $24.00 \%$ and 0.46 to $1.15 \%$, respectively. From the GLM analysis, it was observed that the main effect of cassava variety had significant $(p<0.05)$ effect on the amylose content of the flour samples (Table S1), while the two-way interactive effects of cassava variety and fertiliser type as well as fertiliser type and dosage had 
Table 3. Effect of variety, fertiliser type and dosage on the titratable acidity, pH, starch, sugar, amylose and cyanide content of HQCF.

\begin{tabular}{|c|c|c|c|c|c|c|c|c|}
\hline Variety & $\begin{array}{c}\text { Fertiliser } \\
\text { type (NPK) }\end{array}$ & $\begin{array}{l}\text { Dosage } \\
\text { (kg/ha) }\end{array}$ & $\begin{array}{l}\text { Titratable } \\
\text { Acidity }\end{array}$ & $\mathrm{pH}$ & $\begin{array}{c}\text { Total } \\
\text { starch }(\%)\end{array}$ & $\begin{array}{c}\text { Soluble sugar } \\
(\%)\end{array}$ & $\begin{array}{c}\text { Amylose } \\
(\%)\end{array}$ & $\begin{array}{c}\mathrm{HCN} \\
(\mathrm{mg} / \mathrm{kg})\end{array}$ \\
\hline TMS 30572 & $15-15-15$ & 150 & $15.27 \pm 0.02^{9}$ & $6.12 \pm 0.23^{g h}$ & $83.23 \pm 0.36^{n}$ & $3.77 \pm 0.01^{\text {def }}$ & $20.94 \pm 0.02^{b}$ & $0.95 \pm 0.00^{h}$ \\
\hline TMS 30572 & $15-15-15$ & 300 & $15.16 \pm 0.08^{f}$ & $5.09 \pm 0.86^{\mathrm{a}}$ & $72.31 \pm 0.47^{f}$ & $3.92 \pm 0.00^{f}$ & $23.54 \pm 0.89^{e f}$ & $0.85 \pm 0.02^{f g}$ \\
\hline TMS 30572 & $20-10-10$ & 150 & $16.20 \pm 1.02^{j}$ & $6.19 \pm 0.02^{h}$ & $82.59 \pm 0.02^{\mathrm{m}}$ & $4.42 \pm 0.10^{g}$ & $20.29 \pm 0.48^{a}$ & $0.50 \pm 0.00^{\mathrm{a}}$ \\
\hline TMS 30572 & $20-10-10$ & 300 & $16.95 \pm 0.59^{k}$ & $6.15 \pm 0.00^{g h}$ & $72.90 \pm 1.56^{9}$ & $3.75 \pm 0.43^{\text {cde }}$ & $21.28 \pm 0.39^{b}$ & $0.73 \pm 0.01^{\mathrm{e}}$ \\
\hline TMS 30572 & $12-12-17$ & 150 & $16.90 \pm 0.48^{k}$ & $5.97 \pm 0.01^{\mathrm{ef}}$ & $75.50 \pm 0.78^{j}$ & $3.61 \pm 0.07^{c}$ & $20.94 \pm 0.78^{b}$ & $0.63 \pm 0.00^{b c}$ \\
\hline TMS 30572 & $12-12-17$ & 300 & $15.70 \pm 0.79^{h}$ & $6.24 \pm 0.02^{h}$ & $79.79 \pm 0.57^{\mathrm{k}}$ & $2.70 \pm 0.12^{\mathrm{a}}$ & $21.76 \pm 0.27^{c}$ & $0.46 \pm 0.00^{\mathrm{a}}$ \\
\hline TMS 30572 & NF & - & $9.37 \pm 0.56^{\mathrm{a}}$ & $6.23 \pm 0.04^{h}$ & $74.33 \pm 0.79^{i}$ & $4.40 \pm 0.01^{9}$ & $23.33 \pm 0.95^{\mathrm{e}}$ & $0.81 \pm 0.01^{f}$ \\
\hline TME 419 & $15-15-15$ & 150 & $15.74 \pm 0.79^{h}$ & $5.87 \pm 0.00^{\mathrm{e}}$ & $69.43 \pm 0.04^{b}$ & $3.75 \pm 0.02^{\text {cde }}$ & $22.67 \pm 0.42^{d}$ & $0.66 \pm 0.02^{\mathrm{bcd}}$ \\
\hline TME 419 & $15-15-15$ & 300 & $13.90 \pm 0.37^{b}$ & $5.83 \pm 0.01^{\mathrm{de}}$ & $66.82 \pm 0.36^{\mathrm{a}}$ & $3.70 \pm 0.07^{\mathrm{cd}}$ & $23.58 \pm 0.39^{e f}$ & $0.88 \pm 0.00^{9}$ \\
\hline TME 419 & $20-10-10$ & 150 & $14.79 \pm 0.48^{d}$ & $5.96 \pm 0.02^{\mathrm{ef}}$ & $70.14 \pm 0.56^{d}$ & $3.54 \pm 0.03^{b}$ & $24.00 \pm 0.12^{g}$ & $0.71 \pm 0.01^{\mathrm{de}}$ \\
\hline TME 419 & $20-10-10$ & 300 & $14.95 \pm 0.03^{\mathrm{e}}$ & $6.01 \pm 0.00^{f g}$ & $69.89 \pm 0.36^{c}$ & $3.90 \pm 0.00^{\mathrm{ef}}$ & $21.67 \pm 0.78^{c}$ & $0.68 \pm 0.23^{\text {cde }}$ \\
\hline TME 419 & $12-12-17$ & 150 & $16.07 \pm 0.28^{i}$ & $5.72 \pm 0.03^{d}$ & $72.07 \pm 0.48^{\mathrm{e}}$ & $2.67 \pm 0.00^{\mathrm{a}}$ & $22.83 \pm 0.99^{d}$ & $0.48 \pm 0.18^{\mathrm{a}}$ \\
\hline TME 419 & $12-12-17$ & 300 & $17.68 \pm 0.48^{\prime}$ & $5.23 \pm 0.00^{b}$ & $82.05 \pm 1.09^{\prime}$ & $3.72 \pm 0.00^{\mathrm{cd}}$ & $23.72 \pm 0.14^{\mathrm{fg}}$ & $1.15 \pm 0.02^{i}$ \\
\hline TME 419 & $\mathrm{NF}$ & - & $14.61 \pm 0.71^{\mathrm{C}}$ & $5.44 \pm 0.00^{\mathrm{C}}$ & $73.70 \pm 0.75^{\mathrm{h}}$ & $4.67 \pm 0.00^{\mathrm{h}}$ & $22.77 \pm 0.39^{d}$ & $0.61 \pm 0.00^{b}$ \\
\hline \multicolumn{9}{|c|}{ The superscript is used to show significant differences among the samples. } \\
\hline \multicolumn{9}{|c|}{ Values are means of triplicate determination. } \\
\hline \multicolumn{9}{|c|}{ Mean values with different superscripts within the same column are significantly different $(p<0.05)$. } \\
\hline
\end{tabular}

significant $(p<0.05)$ effect on the total starch content of the samples (Table S2). HQCF from cassava variety TMS 30572 without fertiliser had significantly lowest TTA among the samples. Among the fertilised cassava varieties, TMS 30572 with NPK 15-15-15 at $150 \mathrm{~kg} / \mathrm{ha}$ had the highest total starch (Table 3 ). The three-way interactive effect of the independent variables studied had no effect on any of the parameters studied (Table S3).

$\mathrm{pH}$ is an important parameter in determining the quality of cassava flour. Flour $\mathrm{pH}$ of 4 or less indicates appreciable fermentation and starch breakdown. Fermented flour also imparts a characteristic aroma and flavour to the flour, making it less preferred in baking. In spite of fertiliser application, the flour $\mathrm{pH}$ values obtained in this study were comparable with those reported by Dziedzoave et al. (2006) and fall within the standard specification for HQCF by Africa Regional Standard Organization (ARSO). ApeaBah et al. (2011) reported $\mathrm{pH}$ range between 5.07 and 6.65 for unfertilised HQCF. Starches/flour with high $\mathrm{pH}$ has been reported to have better solubility. This is as a result of increased hydrophilic role of starch at high $\mathrm{pH}$ values (Adebowale et al., 2005). pH value close to 7 has been reported to stimulate retrogradation because of the absence of salts of monovalent anions and cations (Chen et al., 2011). Therefore, the $\mathrm{pH}$ range of 5.09 to 6.24 obtained in this study further revealed that fertiliser application does not have any adverse effect on the usability of the HQCF in food systems.
Amylose and starch have been reported to be the major dry matter constituents of roots (Cadavid et al., 1998). Low amylose composition in starch contributes to an increased relative crystallinity owing to the reduction in the amorphous regions inside the starch granule (Tukomane et al., 2007). Amylose is also an essential factor to attain desirable structure in products and thought to influence the eating quality of starchy food like noodles as well as the sticky properties of pasta (Grant et al., 1993). The amylose and HCN content of HQCF from TMS 30572 cassava variety decreased with fertiliser application, and they increased in TME 419 roots after fertiliser application. Generally, the HCN values obtained in this study are below $10 \mathrm{mg} / \mathrm{kg}$ safe level established for $\mathrm{HCN}$ in cassava flour (FAO, 2013). Cassava variety as well as fertiliser compounding ratio had varying effects on $\mathrm{HCN}$ contents of HQCF. The total starch content for HQCF from TMS 30572 increases with fertiliser application and a reduction in the starch content after fertiliser application was observed in the flour from TME 419 variety. The observed variations may be due to varietal differences.

\section{Effect of cassava varieties, fertiliser type and dosage on functional properties of HQCF}

Table 4 shows the effect of cassava variety, fertiliser type and dosage on functional properties of HQCF. GLM analysis indicates that the most significantly affected 
Table 4 . Effect of cassava varieties, fertiliser type and dosage on functional properties ofHQCF.

\begin{tabular}{|c|c|c|c|c|c|c|c|c|}
\hline Variety & $\begin{array}{l}\text { Fertiliser } \\
\text { type (NPK) }\end{array}$ & $\begin{array}{l}\text { Dosage } \\
\text { (kg/ha) }\end{array}$ & $\begin{array}{l}\text { WAC } \\
(\%)\end{array}$ & $\begin{array}{c}\text { Disp. } \\
(\%)\end{array}$ & $\begin{array}{c}\text { BD } \\
(\mathrm{g} / \mathrm{ml})\end{array}$ & $\begin{array}{l}\text { SP } \\
(\%)\end{array}$ & $\begin{array}{l}\mathrm{SI} \\
(\%)\end{array}$ & LGC \\
\hline TMS 30572 & $15-15-15$ & 150 & $103.85 \pm 1.05^{f}$ & $71.30 \pm 0.96^{\mathrm{e}}$ & $0.58 \pm 0.00^{b}$ & $9.06 \pm 0.07^{h}$ & $9.81 \pm 0.75^{f}$ & $13.97 \pm 0.45^{f}$ \\
\hline TMS 30572 & $15-15-15$ & 300 & $114.56 \pm 0.98^{i}$ & $73.25 \pm 0.57^{g}$ & $0.61 \pm 0.00^{f}$ & $9.94 \pm 0.20^{\prime}$ & $10.13 \pm 0.37^{i}$ & $12.13 \pm 0.29^{b}$ \\
\hline TMS 30572 & $20-10-10$ & 150 & $120.79 \pm 0.56^{k}$ & $68.06 \pm 0.59^{c}$ & $0.62 \pm 0.00^{9}$ & $7.81 \pm 0.08^{\mathrm{e}}$ & $9.55 \pm 0.48^{d}$ & $12.93 \pm 0.26^{c}$ \\
\hline TMS 30572 & $20-10-10$ & 300 & $117.41 \pm 0.79^{j}$ & $72.15 \pm 0.56^{f}$ & $0.58 \pm 0.00^{b}$ & $8.05 \pm 0.01^{g}$ & $10.36 \pm 0.47^{j}$ & $13.10 \pm 0.27^{\mathrm{cd}}$ \\
\hline TMS 30572 & $12-12-17$ & 150 & $121.03 \pm 1.39^{\prime}$ & $74.90 \pm 0.36^{h}$ & $0.60 \pm 0.00^{\mathrm{e}}$ & $7.93 \pm 0.36^{f}$ & $10.99 \pm 0.23^{k}$ & $13.20 \pm 1.05^{\mathrm{cde}}$ \\
\hline TMS 30572 & $12-12-17$ & 300 & $125.26 \pm 2.78^{m}$ & $68.35 \pm 0.75^{c}$ & $0.59 \pm 0.00^{d}$ & $7.26 \pm 0.44^{c}$ & $12.71 \pm 0.71^{\prime}$ & $9.78^{\mathrm{a}} \pm 0.00$ \\
\hline TMS 30572 & $\mathrm{NF}$ & - & $104.88 \pm 0.78^{h}$ & $67.30 \pm 0.27^{b}$ & $0.66 \pm 0.00^{j}$ & $7.13 \pm 0.58^{\mathrm{a}}$ & $15.71 \pm 0.52^{n}$ & $13.48 \pm 0.08^{\mathrm{de}}$ \\
\hline TME 419 & $15-15-15$ & 150 & $125.93 \pm 1.04^{n}$ & $68.15 \pm 0.77^{c}$ & $0.58 \pm 0.00^{b}$ & $9.60 \pm 0.37^{j}$ & $9.51 \pm 0.76^{c}$ & $13.00 \pm 0.47^{c}$ \\
\hline TME 419 & $15-15-15$ & 300 & $77.45 \pm 0.67^{a}$ & $67.25 \pm 0.94^{b}$ & $0.56 \pm 0.00^{\mathrm{a}}$ & $9.95 \pm 0.76^{\prime}$ & $9.26 \pm 0.53^{b}$ & $13.35 \pm 0.48^{\text {cde }}$ \\
\hline TME 419 & $20-10-10$ & 150 & $89.87 \pm 0.39^{b}$ & $65.02 \pm 1.07^{a}$ & $0.64 \pm 0.00^{i}$ & $9.69 \pm 0.65^{\mathrm{k}}$ & $9.74 \pm 0.58^{e}$ & $13.59 \pm 0.07^{\mathrm{ef}}$ \\
\hline TME 419 & $20-10-10$ & 300 & $96.32 \pm 0.37^{d}$ & $70.80 \pm 0.51^{\text {de }}$ & $0.59 \pm 0.00^{d}$ & $9.23 \pm 0.37^{i}$ & $9.95 \pm 0.46^{h}$ & $12.36 \pm 0.48^{b}$ \\
\hline TME 419 & $12-12-17$ & 150 & $99.00 \pm 1.78^{\mathrm{e}}$ & $70.35 \pm 0.79^{d}$ & $0.60 \pm 0.00^{\mathrm{e}}$ & $7.12 \pm 0.89^{\mathrm{a}}$ & $14.42 \pm 0.94^{\mathrm{m}}$ & $9.77 \pm 0.20^{\mathrm{a}}$ \\
\hline TME 419 & $12-12-17$ & 300 & $104.00 \pm 0.56^{\mathrm{g}}$ & $74.30 \pm 1.05^{h}$ & $0.61 \pm 0.00^{f}$ & $7.20 \pm 0.91^{b}$ & $4.63 \pm 0.48^{a}$ & $10.17 \pm 0.05^{\mathrm{a}}$ \\
\hline TME 419 & $\mathrm{NF}$ & - & $92.16 \pm 0.89^{c}$ & $74.25 \pm 0.51^{\mathrm{h}}$ & $0.63 \pm 0.00^{h}$ & $7.41 \pm 0.71^{\mathrm{d}}$ & $9.90 \pm 0.35^{9}$ & $10.13 \pm 0.35^{\mathrm{a}}$ \\
\hline \multicolumn{9}{|c|}{ The superscript is used to show significant differences among the samples. } \\
\hline \multicolumn{9}{|c|}{ Values are means of triplicate determination. } \\
\hline \multicolumn{9}{|c|}{ Mean values with different superscripts within the same column are significantly different $(p<0.05)$. } \\
\hline
\end{tabular}

functional property is the swelling power (Table S4). The swelling power ranged from 7.12 to $9.95 \%$ and was lower than the values reported by Shittu et al. (2008) for fertilised cassava roots, and higher swelling power has been linked with improved digestibility and ability to use the flour in varied dietary applications (Moorthy, 2002). The variations observed may be due to differences in fertiliser compounding ratio and dosage used in the studies. Cassava samples of both varieties fertilised with NPK $15-15-15$ at 150 and $300 \mathrm{~kg} /$ ha gave significantly higher swelling power compared with other fertilised and unfertilised samples. The least gelation concentration (LGC) that ranged from 9.77 to $13.97 \%$ was only affected by fertiliser type and not by cassava variety or fertiliser dosage (Table S5). This may be due to the different fertiliser treatments applied to the cassava roots used in this study. Generally, the interactive effects of fertilizer-type, variety and dosage did not have significant effect on the functional properties of the composite flour (Table S6).

The least gelation concentration (LGC) of flour is an important functional property that determines the minimum flour/water ratio needed to produce gel from cooked flour/water suspension (Shittu et al., 2008). The gelation process is the main avenue for the hydration of protein/carbohydrate polymer system during baking. In this study, the water absorption capacity of HQCF from fertilised root was higher than the control. This indicates that fertiliser application may influence the water absorption tendency of cassava flour. However, a contrary trend was observed in bulk density of HQCF from TMS 30572 and TME 419 as bulk density reduced following fertiliser application, with exception of flour from TME 419 with NPK 20-10-10 at $150 \mathrm{~kg} /$ ha whose bulk density increased after fertiliser application. Generally, the functional properties of HQCF improved following fertiliser application regardless of the compounding factor and dosage used, and this is an indication that fertiliser application to cassava roots could improve the functionality of HQCF in food systems.

\section{Effect of cassava varieties, fertiliser type and dosage on pasting properties of HQCF}

When starchy foods are heated in water, they undergo several changes including gelatinisation and pasting. These are the two most important factors that influence the quality and aesthetic considerations of HQCF application in food industry, since they affect the texture and digestibility as well as the end use of starchy foods (Adebowale et al., 2005). The pasting properties of the HQCF samples as influenced by cassava variety, fertiliser type and dosage are presented in Table 5. GLM analysis revealed that the main effect of cassava variety and the interactive effect of fertiliser type and dosage had significant effect on the peak and pasting temperature of the flour samples (Table S7). In addition, the interactive effect of cassava variety and fertiliser dosage had significant effect on pasting temperature, while the interaction of fertiliser 
Table 5. Effect of cassava varieties, fertiliser type and dosage on pasting properties of HQCF.

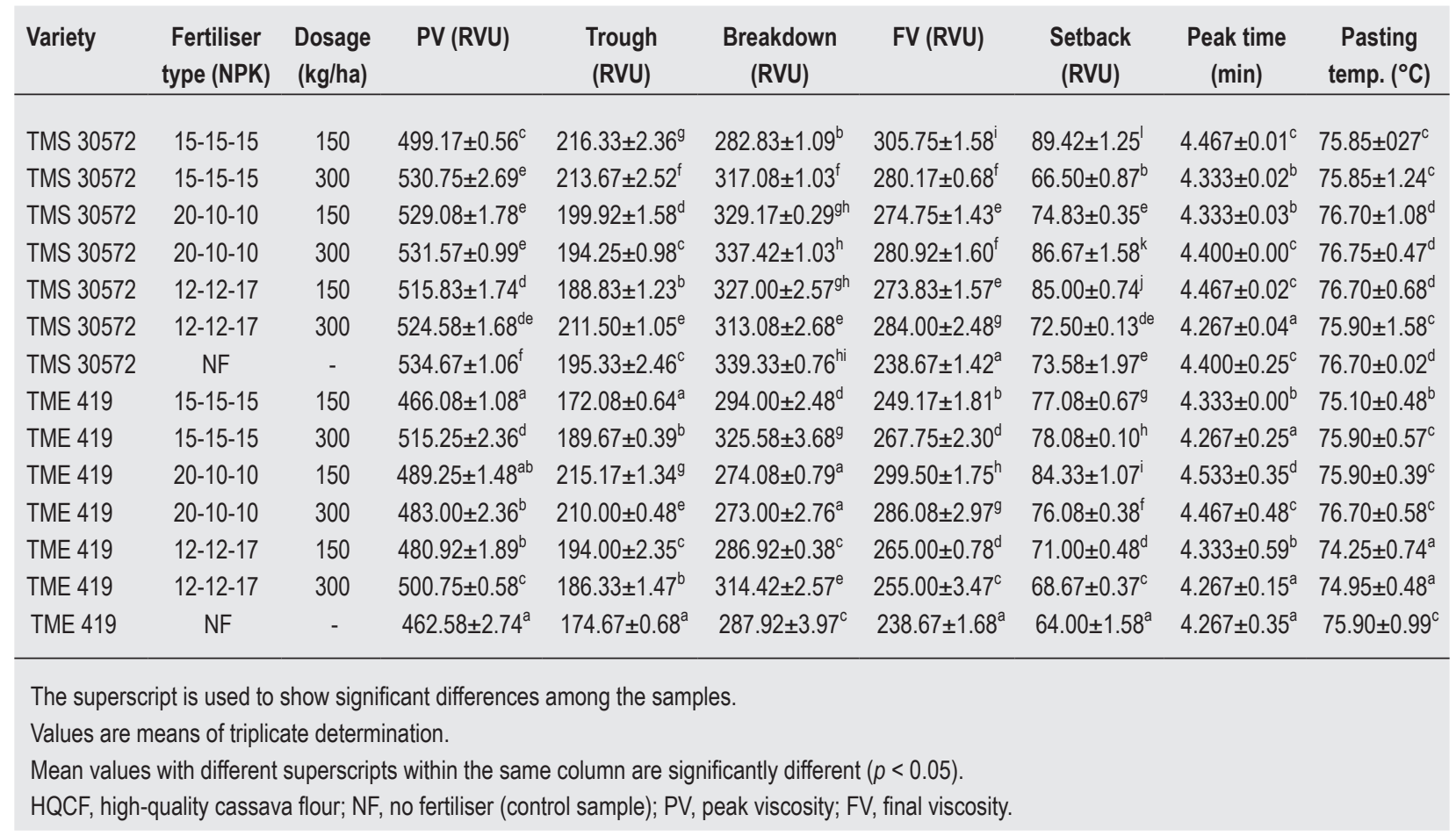

type and cassava variety significantly affected the breakdown viscosity and pasting temperature of the flour samples (Table S8). Also, the three-way interactive effect of cassava variety, fertiliser type and dosage had significant effect on the peak viscosity of the HQCF flours (Table S9).

The peak viscosity of the flour samples ranged from 462.58 to 534.67 RVU. The highest peak viscosity was recorded in the flour from unfertilised TMS 30572, while the flour from unfertilised TME 419 had the lowest peak viscosity value. The peak viscosity of HQCF samples from TMS 30572 reduced following fertiliser application, while the peak viscosity of flour samples from TME 419 increased following fertiliser application. The peak viscosity is often related with the final product quality, as it indicates the viscous load likely to be encountered during mixing (Maziya-Dixon et al., 2004). The variations observed may be due to varietal differences as cassava roots react differently to fertiliser treatment. The values obtained for breakdown value which measures the ability of paste to withstand breakdown during cooling in this study were higher than that reported by Shittu et al. (2008) for HQCF from fertilised roots. The trough which provides information about the breakdown or stability of gel during cooking of starch (Fadimu et al., 2018) was not significantly affected by any of the independent factors.

The final viscosity is the change in the viscosity after holding cooked starch at $50^{\circ} \mathrm{C}$. It is one of the most common parameters used to define the quality of a particular starch-based sample, as it indicates the ability of the flour to form a viscous paste or gel after cooking and cooling as well as the resistance of the paste to shear force during stirring (Adebowale et al., 2008). In our study, the final viscosity values were significant $(p<0.05)$ and the highest value of 305.75 RVU was recorded in the HQCF from TMS 30572 with NPK 15-15-15 at $150 \mathrm{~kg} / \mathrm{ha}$, while the unfertilised TME 419 and TMS 30572 flour samples had the lowest final viscosity. Pasting temperature is the temperature at which permanent swelling of starch granules takes place leading to peak viscosity (Liang and King, 2003). Reaching the pasting temperature is important in ensuring swelling, gelatinisation and gel formation during food processing (Eke-Ejiofor and Owuno, 2012). The range of pasting temperature obtained in this study was slightly higher than values of $78.03-79.30^{\circ} \mathrm{C}$ reported by Shittu et al. (2008) for cassava flour from fertilised roots and Oduro et al. (2000) on seven related roots and tubers.

Higher pasting temperature is associated with high paste stability usually considered as a desirable functional property. Low paste temperature and paste stability are suggestive of fewer associative force and cross-links within the starch granules. This thus indicates that the cassava flours from this study will be desirable in food applications. Usually when factorial analysis shows interactive effect of certain factors, it indicates that singular factor may not be solely responsible for the observed effect on the outcome. In this study, 
the significant interaction observed between fertiliser type and dosage, variety and dosage as well as fertiliser type and variety on the pasting properties indicates that the pasting characteristics may be dependent of certain biogenesis in the cassava plant tissue. However, in the analysis of the main effect, the influence of the different varieties of cassava was highly significant $(p<0.01)$ in the peak viscosity of the HQCF samples.

\section{Conclusions}

This study revealed that cassava varieties and fertiliser treatment have great impact on the functionality of HQCF in food systems. The functional and pasting properties of the HQCF samples improved following fertiliser application to the cassava varieties studied. Dosage of fertiliser did not show significant influence on the flour properties. The effect of fertiliser compounding ratio had significant effect on the swelling power and least gelation concentration of the HQCF samples, while the interaction of fertiliser type and dosage also affected swelling power. Peak viscosity was the most significantly influenced parameter of all the pasting properties by treatment factors. Pasting temperature was also affected by cassava variety, as well as by the interaction of fertiliser type and dosage. However, pasting temperature reduced in most flour samples with fertiliser application compared to their respective control samples. Contrary to an existing belief that fertiliser application during cassava growing stage could have negative effect on HQCF quality, this research has established that fertiliser application during the field cultivation of cassava root could improve the functional and pasting properties of HQCF produced from such roots.

\section{Conflict of interest}

The authors declare no conflicts of interest with respect to research, authorship and/or publication of this article.

\section{Funding}

This research received no specific grant from any funding agency in the public, commercial or not-for-profit sectors.

\section{Compliance with ethical standards}

This article followed all ethical standards for a research without direct contact with human or animal subjects.

\section{References}

Adebowale, A.A., Sanni, L.O. and Awonorin, S.O., 2005. Effect of texture modifiers on the physicochemical and sensory properties of dried fufu. Food Science and Technology International 11(5): 373-382. https://doi.org/10.1177/1082013205058531

Adebowale, A.A., Sanni, L.O. and Onitilo, M.O. 2008. Chemical composition and pasting properties of tapioca grits from different cassava varieties and roasting methods. African Journal of Food Science 2: 72-82.

Adekunle, A.A., Fatumbi, A.O. and Sanni, L.O., 2012. Commercial utilisation of cassava in Nigeria-An illustrated guide. IITA, Ibadan.

Adeyemi, I.A. and Idowu, M.A., 1990. The evaluation of pre-gelatinised maize flour in the development of Massai, a baked product. Nigerian Food Journal 8: 63-73.

AOAC, 2000. Official methods of analysis. Association of Official Analytical Chemist, Washington, DC.

Apea-Bah, F.B., Oduro, I., Ellis, W.O. and Safo-Kantanka, O., 2011. Factor analysis and aga at harvest effect on the quality of flour from four cassava varieties. World Journal of Dairy and Food Science 6(1): 43-54.

Aryee, F.N.A., Oduro, I., Ellis, W.O. and Afuakwa, J.J., 2006. Physicochemical flour samples from the roots of 31 varieties of cassava. Food Control 17(11): 916-922. https://doi.org/10.1016/j. foodcont.2005.06.013

Assanvo, J.B., Agbo, G.N., Behi, Y. Coulin, P. and Farah, Z., 2006. Microflora of traditional starter made from cassava for 'attiéké' production in Dabou (Cóte d'Ivoire). Food Control 17: 37-41. https://doi.org/10.1016/j.foodcont.2004.08.006

Balagopalan, C., 2002. Crop utilization and biotechnology. Central Tuber Crops. Research Institute, Sreekariyan, Kerala, India.

Cadavid, L.F., El-Sharkawy, M.A., Acosta, A. and Sanchez, T., 1998. Long-term effects of mulch, fertilization and tillage on cassava grown in sandy soils in northern Colombia. Field Crops Research 57: 45-56. https://doi.org/10.1016/S0378-4290(97)00114-7

Chen, Z., Schols, H and Voragen, A., 2011. Physicochemical properties of starch obtained from three varieties of Chinese sweet potatoes. Journal of Food Science 68: 431-437. https://doi. org/10.1111/j.1365-2621.2003.tb05690.x

Coffman, C. and Garcia, V.V., 1977. Functional properties of protein isolate from mung bean flour. Journal Food Technology 12: 473-484. https://doi.org/10.1111/j.1365-2621.1977.tb00132.x

Darkwa, N.A. and Jetuah, F.K., 2003. Survey of plywood and paperboard factories. DFID crop post -harvest programme, final report on project output 2.2.2, project R8268. Forestry Research Institute of Ghana, Kumasi, Ghana.

Defloor, I., Nys, M. and Delcour, J.A., 1993. Wheat starch, cassava starch, and cassava flour impairment of the bread making potential of wheat flour. Cereal Chemistry 78: 525-530.

Dziedzoave, N.T., Abass, A.B., Amoa-Awua, W.K.A. and Sablah, M., 2006. Quality management manual for production of high quality cassava flour. International Institute of Tropical Agriculture, Ibadan, Nigeria. 68. Available at: https://hdl.handle.net/10568/91815

Eke-Ejiofor, J. and Owuno, F., 2012. Functional and pasting properties of wheat/three-leaved yam (Dioscorea dumentorum) composite flour blend. Global Research Journal of Agricultural and Biological Science 3(4): 330-335.

Essers, A.A., Bosvel, M., Van der Grift, R. and Voragen, A.1993. Studies on the quantification of specific cyanogens in cassava products and introduction of a new chromogen. Journal of Science 
of Food and Agriculture 63: 287-296. https://doi.org/10.1002/ jsfa.274.0630305

Fadimu, G.J., Sanni, L.O., Adebowale, A.A., Kareem, S.O., Sobukola, O.P., Kajihausa, O.E., Abdulsalam-Saghir, P., Siwoku, B.O., Akinsanya, A.O. and Adenekan, M.K., 2018a. Optimization of pretreatment conditions for plantain (Musa parasidiaca) flour using Box-Behnken design. Quality Assurance and Safety of Crops \& Foods 10(3): 223-232. https://doi.org/10.3920/QAS2017.1216

Fadimu, G.J., Sanni, L.O., Adebowale, A.A., Kareem, S.O., Sobukola, O.P., Kajihausa, O.E., Abdulsalam-Saghir, P., Siwoku, B.O., Akinsanya, A.O. and Adenekan, M.K., 2018b. Effect of drying methods on the chemical composition, colour, functional and pasting properties of plantain (Musa parasidiaca) flour. Croatian Journal of Food technology, Biotechnology and Nutrition 13 (1-2): 38-43.

FAOSTAT, 2019. Food and Agriculture Organisation of the United Nations. Available at: http://www.fao.org/faostat/en/\#data/QC.

Gomez, J.C., Howeler, R.H. and Webber, E.J., 1980. Cassava production in low fertility soils. In: Toro, M.J.C. and Graham, M. (eds.) Cassava cultural practices. Bowker Publication. Co Ltd, Epping, UK, pp. 25-28.

Grant, L.A., Dick, J.W. and Shelton, D.R., 1993. Effects of drying temperature, starch damage, sprouting, and additives on spaghetti quality characteristics. Cereal Chemistry 70: 676-684.

Izutsu, T. and Wani, K., 1985. Food texture and taste: a review. Journal of Texture Studies 16(1): 1-28. https://doi. org/10.1111/j.174.5-4603.1985.tb00677.x

Kulkarni, D.N. and Ingle, U.M., 1991. Sorghum malt based weaning food formulations: preparation, functional properties and nutritive value. Food and Nutrition Bulletin 13(4): 322-327. https:// doi.org/10.1177/156482659101300401

Leach, H.W., Mcwen, L.D. and Schoch, T.J., 1959. Structure of the starch granule. 1. Swelling and solubility patterns of various starches. Cereal Chemistry 36: 534-544.

Liang, X. and King, J.M., 2003. Pasting and crystalline properties differences of commercial and isolated rice starch with added amino acids. Journal of Food Science 68: 3. https://doi. org/10.1111/j.1365-2621.2003.tb08251.x

Maziya-Dixon, B., Dixon, A.G.O. and AdebowaleA.A., 2004. Targeting different end uses of cassava: genotypic variations for cyanogenic potentials and pasting properties. A Paper Presented at ISTRC-AB Symposium, 31 October - 5 November 2004, Whitesands Hotel, Mombassa, Kenya.

Mensah, A.A., 2013. Comparative evaluation of physicochemical and functional properties of cassava a flour from different fertilizer protocols. PhD Thesis, Kwame Nkrumah University of Science and Technology. (KNUST), Kumasi, Ghana

Moorthy, S., 2002. Tuber crop starches. Tech Bulletin No.18, CTCRI, Trivandrum.
Nweke, F.I., 1996. Cassava: a cash crop in Africa. COSCA Working Paper No. 14. Collaborative Study of Cassava in Africa, International Institute of Tropical Agriculture, Ibadan, Nigeria.

Oduro, I., Ellis, W.O., Aryee, S.K., Ahenkora, K. and Otoo, J.A., 2000. Pasting characteristics of starch from new varieties of sweet potato. Tropical Science 40: 25-28.

Onitilo, M.O., Sanni, L.O., Oyewole, O.B. and Maziya-Dixon, B., 2007. Physico-chemical and functional properties of sour starches from different cassava varieties. International Journal of Food Properties 10: 607-620. https://doi.org/10.1080/10942910601048994

Oparah, C.C., Edem, U.B. and Anierobi, B.U., 2013. Deep fat frying properties of malted sorghum buns with cassava and rice flour as binders. Greener Journal of Agricultural Sciences 3(2): 185

Oti, E., Olapeju, O., Dohou, S., Moutairou, E., Nankagninou, D., Komlaga, G.A. and Loueke, G.M., 2010. Processing of cassava into gari and high quality cassava flour in West Africa. Training manual (draft). USAID.

Plucknett, D.L., Philips, T.P. and Kagho, R.B., 1998. A global development strategy for cassava: transforming a traditional tropical root. Paper presented at Asian Cassava Stakeholders' consultation on a global cassava development strategy at Bangkok, Thailand, 23-25 November 1998.

Sanni, L.O., Maziya-Dixo, B., Akanya, C.I., Alaya, Y., Egwuonwu, C.V., Okechukwu, R.U., Ezedinma, C., Akoroda, M., Lemchi, J., Ogbe, F., Okoro, E., Tarawali, G., Mkumbira, J., Patino, M., Ssemakula, G., Dixon, A. 2005. Standards for cassava products and guidelines for export. International Institute of Tropical Agriculture, Ibadan, Nigeria, pp. 11-39.

Sathe, S.K. and Salunkhe, D.E., 1981. Functional properties of lupid seed (Lupinus mutabilis) proteins and protein concentrates. Journal of Food Science 46: 149-197.

Shittu, T.A., Dixon, A., Awonorin, S.O., Sanni, L.O. and MaziyaDixon, B., 2008. Bread from composite cassava-wheat flour: II. Effect of cassava genotype and nitrogen fertilizer on bread quality Food Research. International 40: 280-290. https://doi. org/10.1016/j.foodres.2006.10.012

Sornyotha, S., Kyu, K.L. and Ratanakhanokchai, K., 2010. An efficient treatment for detoxification process of cassava starch by plant cell wall-degrading enzymes, Journal of Bioscience and Bioengineering 109(1): 9-14. https://doi.org/10.1016/j.jbiosc.2009.06.021

Tukomane, T., Leerapongnun, P., Shabsngob, S. and Varavinit, S., 2007. Preparation and characterization of Annealed-Enzymatically Hydrolyzed Tapioca Starch and the Utilization in Tableting. Starch/ Starke 59: 33-45. https://doi.org/10.1002/star.200600524.

Williams, P.C., Kuzina, F.D. and Hylinka, I., 1970. A rapid colorimetric method for estimating amylose content of starches and flours. Cereal Chemistry 47: 411-421. 